\title{
Wyzwania dla przedsiębiorstw finansowych w obszarze transferu nowych technologii
}

\section{The challenges of new technologies transfer done by financial enterprises}

Streszczenie. Niniejszy artykuł ma charakter empiryczny i stanowi próbę identyfikacji czynników zarówno stymulujących, jak i hamujących działające w Polsce przedsiębiorstwa finansowe do podejmowania transferu technologii na rzecz rozwoju posiadanego potencjału technologicznego.

Uzyskane wyniki badań sugerują, iż w analizowanym sektorze panują sprzyjające warunki dla podejmowania aktywności zmierzającej do transferu technologii. Okazuje się bowiem, że reprezentujące go przedsiębiorstwa dostatecznie wyraźnie dostrzegają w swym otoczeniu możliwości czy też zagrożenia, które skłaniają je do angażowania się w absorpcję pochodzących z zewnątrz technologii. I choć z drugiej strony napotykają na rzeczywiste trudności, to jednak - co do zasady - są w stanie im sprostać. 
Słowa kluczowe: technologie, rozwój technologiczny, transfer technologii

\begin{abstract}
The paper is of empirical character and it is an attempt to identify both stimulating and hindering factors influencing the financial enterprises operating in Poland in the field of technology transfer focused on the development of their technological potential.

The research findings suggest that in the analysed sector there are favourable conditions for being active in the area of technology transfer. As it follows from the analysis, the representatives of financial sector recognize environmental opportunities as well as threats that induce them to engage in absorbing external technologies. Although financial enterprises face some real obstacles, in general they overcome them.
\end{abstract}

Keywords: technologies, technological development, technology transfer

\title{
1. Wprowadzenie
}

Technologia odgrywa niezwykle ważną i bez wątpienia niekwestionowaną rolę $\mathrm{w}$ tym, co dla przedsiębiorstwa jest najważniejsze, a mianowicie w generowaniu rynkowych i finansowych wyników jego działalności. Wynika to z bezpośredniego wpływu, jaki ma na kształtowanie instrumentów oddziaływania na klienta, a tym samym na poziom atrakcyjności oferty rynkowej. Stąd też technologiczny rozwój przedsiębiorstwa wydaje się współcześnie warunkiem koniecznym jego sukcesu, jako że jest oczywistym źródłem zdolności do skutecznego rywalizowania o względy klientów na coraz bardziej konkurencyjnych rynkach.

Wymagające środowisko sektorowe stawia przed przedsiębiorstwami zwykle bardzo ambitne wyzwania technologiczne, którym nie zawsze są w stanie sprostać samodzielnie. Będące konsekwencją tych wyzwań protechnologiczne aspiracje przedsiębiorstw, często są niestety „studzone” ich ograniczonymi możliwościami, zwykle finansowymi i kompetencyjnymi, ale także technicznymi czy kadrowymi. 
Dlatego budując swój potencjał technologiczny są one zmuszone posiłkować się rozwiązaniami pochodzącymi z zewnątrz, zwłaszcza z innych firm, uniwersytetów, rządowych bądź komercyjnych laboratoriów ${ }^{1}$. A niekiedy absorpcja istniejących już w otoczeniu technologii stanowi dla nich jedyną dostępną sposobność na osiągnięcie pożądanego poziomu konkurencyjności.

Korzystanie z obcych osiągnięć naukowo-technicznych stało się szeroko rozpowszechnioną praktyką gospodarczą również dlatego, że stanowi ona najkrótszą, najbardziej opłacalną i obciążoną względnie najniższym ryzykiem sposobność doskonalenia swojego potencjału technologicznego ${ }^{2}$. Trudno obecnie nawet wyobrazić sobie przedsiębiorstwo, które w ogóle nie korzystałoby lub nie było zainteresowane tą formą rozwoju. I w takim oto kontekście wyłania się doniosła współcześnie rola transferu technologii, stanowiącego bezcenne narzędzie w budowaniu zdolności konkurencyjnych przedsiębiorstwa.

Przyjmując, iż technologia jest strategicznym zasobem przedsiębiorstwa, a transfer technologii skutecznym sposobem jej rozwoju, analizę czynników procesu transferu technologii należy uznać za bardzo ważny przedmiot badań, warunkujący rynkowy sukces przedsiębiorstwa. Stąd w ramach niniejszego opracowania, mającego charakter empiryczny, autor podejmuje się próby odpowiedzi na pytanie, czy warunki panujące $\mathrm{w}$ otoczeniu działających w Polsce przedsiębiorstw usług finansowych skłaniają je do absorbowania pochodzących z zewnątrz gotowych rozwiązań technologicznych czy też może zniechęcają. Tym samym stawia sobie za cel dokonanie identyfikacji i oceny szans oraz zagrożeń, które stymulują lub hamują aktywność badanych przedsiębiorstw $\mathrm{w}$ zakresie transferu technologii.

Źródłem danych niezbędnych do realizacji założonych przez autora zamierzeń empirycznych były badania własne przeprowadzone metodą ankiety bezpośredniej wśród działających w Polsce przedsię-

\footnotetext{
${ }^{1}$ V.K. Narayanan, Managing technology and innovation for competitive advantage, Prentice Hall, New Jersey 2001, s. 325.

2 E. Stawasz, Innowacje a mała firma, Wydawnictwo Uniwersytetu Łódzkiego, Łódź 1999, s. 21.
} 
biorstw usług finansowych. Kompletnie wypełnione kwestionariusze ankiety pozyskano od 90 podmiotów, w tym od 20 zakładów ubezpieczeń na życie i 20 zakładów ubezpieczeń majątkowych oraz 20 banków, 20 towarzystw funduszy inwestycyjnych i 10 powszechnych towarzystw emerytalnych.

\section{Otoczenie jako źródło wyzwań dla transferu technolo- gii}

Źródłem rozwoju technologicznego przedsiębiorstwa mogą być jego wewnątrzorganizacyjne wysiłki podejmowane na rzecz tworzenia i doskonalenia nowych technologii bądź szeroko rozumiane otoczenie $^{3}$. Transfer technologii jawi się zatem jako alternatywny, względem działalności badawczo-rozwojowej, sposób wzbogacania potencjału technologicznego. Przy czym należy go rozumieć jako wykorzystanie technologii w nowych zastosowaniach bądź u nowego użytkownika w celu osiągnięcia korzyści ekonomicznych ${ }^{4}$ czy po prostu jako aplikowanie określonej technologii w nowym zastosowaniu lub przez nowego użytkownika5.

Aby proces transferu technologii stał się rzeczywistym motorem rozwoju przedsiębiorstwa, musi być odpowiednio często podejmowany, a następnie we właściwy, a zwłaszcza skuteczny sposób realizowany. Istnieje zatem potrzeba poszukiwania, a także kreowania jak najlepszych warunków dla przenoszenia istniejących w otoczeniu technologii do wewnątrzorganizacyjnego zastosowania, dającego jednostce jak największe korzyści. Należy zauważyć przy tym, że warunki zewnętrzne są w zasadzie takie same dla wszystkich przedsiębiorstw w sektorze. Jednak jedne przedsiębiorstwa potrafią je skuteczniej identyfikować i trafniej oceniać ich wpływ, a następnie lepiej

\footnotetext{
${ }^{3}$ J.A. Miles, Management and Organization Theory, Jossey-Bass Reader, San Francisco 2012, s. 17.

${ }_{4}$ T. Agmon, M.A. von Glinow, Technology transfer in international business, Oxford University Press, New York 1991, s. 1.

5 P. Trott, Innovation Management and New Product Development, Prentice Hall, Harlow 2008, s. 323.
} 
je wykorzystywać lub też lepiej się do nich adaptować, a inne - gorzej. Zatem zdolności do identyfikowania, a następnie właściwego reagowania na występujące $\mathrm{w}$ otoczeniu szanse i zagrożenia dla transferu technologii determinują sukces tego procesu, a tym samym pożądany rozwój technologiczny w przedsiębiorstwie. Same umiejętności prowadzenia analizy otoczenia oraz dostosowywania się do dostrzeżonych w nim zjawisk, jak również wiedza na ten temat, stanowią już jednak uwarunkowania wewnętrzne.

Należy w związku z tym pamiętać, iż otoczeniem dla podmiotu pozyskującego nową technologię jest wszystko to, co do niego nie należy, a ma wpływ na dokonywany przez niego transfer6. Rozpoznanie wszystkich potencjalnie istotnych czynników procesu transferu technologii wymaga wyznaczenia konkretnych obszarów poszukiwań, które stanowiąc drogowskaz metodycznego postępowania, umożliwiają przeprowadzenie wnikliwej i kompleksowej analizy otoczenia. W konsekwencji przedsiębiorstwo może liczyć na to, iż dostrzeże szanse bądź zagrożenia, które nie będą jeszcze widoczne dla konkurentów lub nawet umkną ich uwadze, dzięki czemu będzie mogło odpowiednio szybko, a może również lepiej na nie zareagować.

W literaturze przedmiotu istnieją liczne, choć zwykle bardzo zbliżone do siebie koncepcje podziału otoczenia organizacji na określone segmenty. Najczęściej w pierwszej kolejności otoczenie dzielone jest na dalsze (zwane makrootoczeniem) i bliższe (zwane konkurencyjnym czy sektorowym), gdzie to dalsze stanowi zbiór czynników silnie określających możliwości działania i rozwoju przedsiębiorstwa, ale nie podlegających jego wpływom ${ }^{7}$. Natomiast między elementami otoczenia konkurencyjnego a funkcjonującym $\mathrm{w}$ nim przedsiębiorstwem zachodzą sprzężenia zwrotne, co oznacza, że to przedsiębior-

\footnotetext{
${ }^{6}$ Zob. np.: J.A.F. Stoner, R.E. Freeman, D.R. Gilbert, Jr., Kierowanie, PWE, Warszawa 2001, s. 79 czy S.P. Robbins, Management. Concepts and applications, Printice-Hall International, New Jersey 1988, s. 70.

${ }^{7}$ G. Gierszewska, M. Romanowska, Analiza strategiczna przedsiębiorstwa, PWE, Warszawa 2003, s. 34-35.
} 
stwo też może aktywnie na nie oddziaływać, a tym samym współtworzyć dla siebie warunki działania.

W dalszym etapie makrootoczenie dzieli się - co do zasady - na otoczenie przyrodnicze, techniczne, ekonomiczne, społeczne, kulturowe, demograficzne, polityczne i prawne, a nawet międzynarodowe ${ }^{8}$. Z kolei w ramach otoczenia konkurencyjnego wyodrębnia się konkurentów - tych obecnych, jak i potencjalnych, producentów substytutów oraz dostawców i nabywców 9 .

$\mathrm{W}$ tak oto ustrukturyzowanym otoczeniu należy doszukiwać się konkretnych, ściśle określonych czynników, które mogą stanowić szanse lub zagrożenia dla podejmowanej na rzecz transferu technologii działalności. Sama jednak wiedza o ich występowaniu nie stanowi o wyższości przedsiębiorstwa względem konkurentów w procesie doskonalenia potencjału technologicznego. Dopiero aktywne wykorzystanie zidentyfikowanej okazji lub przeciwstawienie się wyłaniającemu niebezpieczeństwu daje możliwość zdobycia technologicznej przewagi i zastosowania wygrywających rozwiązań rynkowych.

Proponowany przez P. Trotta mechanizm identyfikowania i wykorzystywania zewnętrznych uwarunkowań został zaprezentowany na rysunku 1.

\footnotetext{
${ }^{8}$ S. Sudoł, Przedsiębiorstwo. Podstawy nauki o przedsiębiorstwie. Zarządzanie przedsiębiorstwem, PWE, Warszawa 2006, s. 46.

9 M.E. Porter, Competitive Strategy. Techniques for Analyzing Industries and Competitors, The Free Press, New York 1998, s. 4.
} 
Rysunek 1. Koncepcja rozwoju biznesowych i technologicznych możliwości przedsiębiorstwa

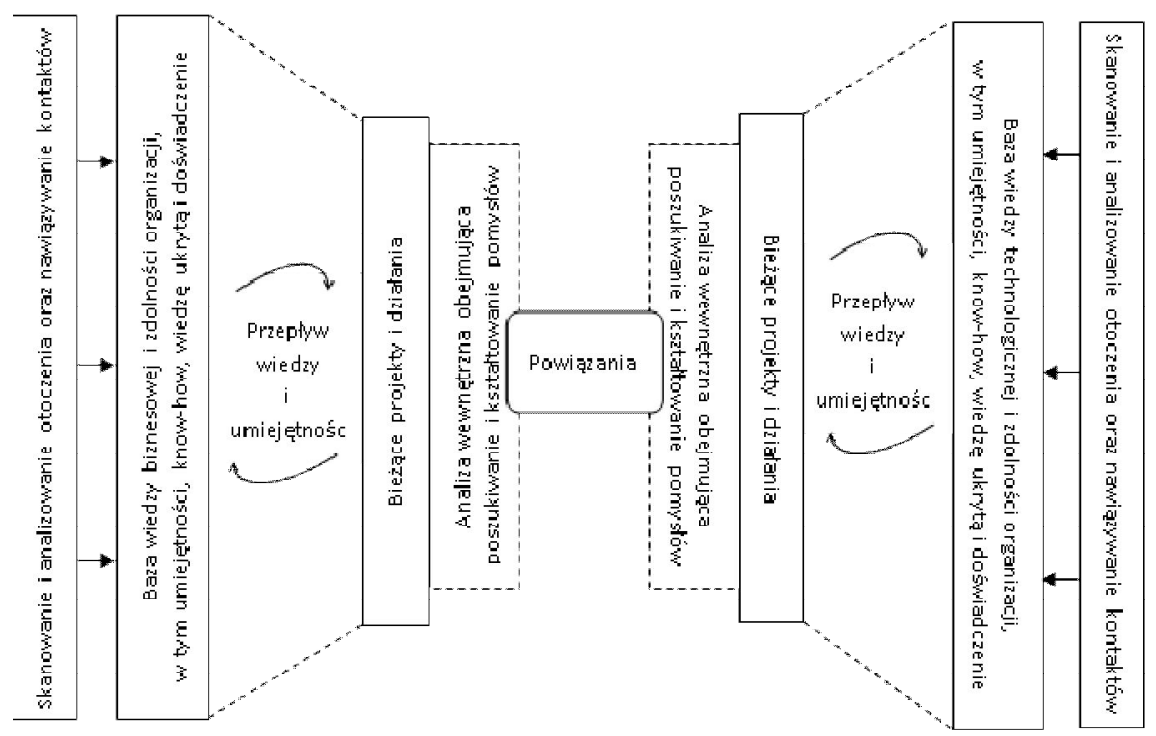

Źródło: P. Trott, op. cit., s. 335.

Powyższa koncepcja prezentuje mechanizm identyfikowania w otoczeniu przesłanek rozwoju przedsiębiorstwa, które wzbogacają jego integrujące się wzajemnie zasoby wiedzy biznesowej i technologicznej, stanowiąc podstawę do działania w oparciu o wewnętrzny potencjał. Np. analizując otoczenie w celu znalezienia właściwej innowacyjnej technologii, należy wziąć pod uwagę jej dopasowanie do zidentyfikowanych szans rynkowych uwzględniając jednocześnie wewnętrzne zdolności organizacji, które uprzednio winny być poddane samoocenie ${ }^{10}$. Zatem analiza otoczenia musi mieć charakter wielowymiarowy i być zawsze powiązana $\mathrm{z}$ analizą wnętrza przedsiębiorstwa, gdyż warunkuje to realność wyznaczanych celów i skuteczność podejmowanych przez nie działań, również w zakresie rozwoju technologicznego.

\footnotetext{
10 Por. P. Trott, op. cit., s. 335.
} 


\section{Rzeczywiste szanse i zagrożenia dla aktywności przed- siębiorstw na rzecz transferu technologii}

Kadra kierownicza działających w Polsce przedsiębiorstw usług finansowych wydaje się być świadoma potrzeby rozwoju swojego potencjału technologicznego, na co wskazują przedstawione w tabeli 1 wyniki przeprowadzonych przez autora badań empirycznych.

Tabela 1. Brak inwestycji przedsiębiorstw w nowe technologie

\begin{tabular}{|l|c|}
\hline \multicolumn{1}{|c|}{ Rodzaje technologii } & $\begin{array}{c}\text { \% udzial przedsiębiorstw } \\
\text { nie inwestujących w nowe technologie }\end{array}$ \\
\hline Nowa technologia projektowania usług & 18 \\
\hline Nowa technologia świadczenia usług & 0 \\
\hline Nowa technologia sprzedaży usług & 2 \\
\hline
\end{tabular}

Źródło: opracowanie własne na podstawie wyników badań ankietowych.

Według zaprezentowanych danych, w ostatnich 3 latach wszystkie indagowane podmioty inwestowały w nowe technologie świadczenia usług, a zaledwie $2 \%$ zaniechało inwestycji w nowe technologie sprzedaży usług i $18 \% \mathrm{w}$ nowe technologie projektowania usług. A zatem działające w Polsce przedsiębiorstwa finansowe wykazują się bardzo wysoką aktywnością podejmowaną na rzecz rozwoju technologicznego, w ramach którego ogromną rolę odgrywa forma transferu'11, czemu z kolei dowodzą wyniki badań zaprezentowane w tabeli 2 .

Okazuje się, że przedsiębiorstwa finansowe, które wdrażały w ostatnich latach nowe technologie, powszechnie pozyskiwały je ze swojego otoczenia. Zaledwie $8 \%$ badanych podmiotów nie wykorzystało formy transferu w przypadku inwestycji w nowe technologie

\footnotetext{
11 Szerzej na temat protechnologicznej aktywności działających w Polsce przedsiębiorstw usług finansowych zob. W. Glabiszewski, Transfer technologii $w$ działalności innowacyjnej przedsiębiorstw ustug finansowych, „Zeszyty Naukowe Ekonomia i Zarządzanie” 2013, t. VI, s. 27-46.
} 
sprzedaży usług, a 19\% w przypadku inwestycji w nowe technologie projektowania i świadczenia usług.

Tabela 2. Brak aktywności przedsiębiorstw w zakresie wykorzystania transferu technologii

\begin{tabular}{|l|c|}
\hline \multicolumn{1}{|c|}{ Rodzaje technologii } & $\begin{array}{c}\text { \% udzial przedsiębiorstw } \\
\text { nie wykorzystujących transferu } \\
\text { technologii }\end{array}$ \\
\hline Nowa technologia projektowania usług & 19 \\
\hline Nowa technologia świadczenia usług & 19 \\
\hline Nowa technologia sprzedaży usług & 8 \\
\hline
\end{tabular}

Źródło: opracowanie własne na podstawie wyników badań ankietowych.

Bacząc na imponującą aktywność badanych przedsiębiorstw w zakresie wykorzystywania transferu technologii, można domniemywać, że napotykały one w ostatnich latach na sprzyjające warunki doskonalenia swojego potencjału technologicznego właśnie tą drogą. Niewątpliwie jednak znalazły się też i takie przedsiębiorstwa finansowe, którym w obliczu zaistnienia realnych barier nie udało się wprowadzić istotnych zmian technologicznych. Stąd też podjęta przez autora w dalszej części opracowania próba identyfikacji tych czynników - zarówno o charakterze stymulującym, jak i hamującym - wydaje się być użyteczna z punktu widzenia kształtowania i wykorzystywania $\mathrm{w}$ praktyce odpowiednich warunków dla budowania silnego potencjału technologicznego za sprawą transferu technologii.

W pierwszej kolejności podjęta została próba odpowiedzi na pytanie: jakie elementy otoczenia zachęcają przedsiębiorstwa usług finansowych do absorbowania z zewnątrz nowych technologii? Ocena stymulującego wpływu poszczególnych czynników na podejmowanie transferu technologii była dokonana w skali od 1 do 5, której skrajne kategorie oznaczały odpowiednio: „zdecydowanie nieważne” oraz „bardzo ważne”. Środkowa kategoria skali to ocena neutralna, interpretowana jako "trudno powiedzieć”. W konsekwencji odpowiedzi wskazujące oceny od 4 do 5 informują o znaczących, a od 1 do 
2 o mało istotnych stymulatorach podejmowania transferu technologii jako sposobu rozwoju potencjału technologicznego.

Powyższej ocenie poddano listę czynników sprzyjających podejmowaniu transferu technologii, które zostały zidentyfikowane i zestawione $\mathrm{w}$ oparciu o przestudiowaną literaturę przedmiotu. Indagowanym menedżerom umożliwiono uzupełnienie zaproponowanej im listy stymulatorów (jak i w dalszej części badań - destymulatorów) o takie, które są dostrzegane i odczuwane przez nich, a nie zostały uwzględnione $\mathrm{w}$ kwestionariuszu ankiety. Żaden z nich nie skorzystał jednak z tej możliwości. Otrzymane wyniki, będące średnimi arytmetycznymi wyliczonymi dla ocen dokonanych przez przedstawicieli wszystkich badanych przedsiębiorstw, zostały zaprezentowane w tabeli 3.

Jak sygnalizuje zaprezentowane zestawienie, kadra kierownicza działających w Polsce przedsiębiorstw finansowych dostrzega niebagatelne znaczenie poszczególnych czynników, oceniając ich wpływ jako raczej wysoki. Średnio rzecz biorąc, wszystkie poddane analizie zewnętrzne stymulatory są postrzegane jako znacząco sprzyjające $w$ podejmowaniu transferu technologii. Najsilniejszy wpływ na badane podmioty - co nie wydaje się być zaskoczeniem - ma możliwość wcześniejszego zweryfikowania skuteczności nowych technologii przez dotychczasowych użytkowników oraz wysoka opłacalność ich wdrażania drogą transferu, a przynajmniej wyższa względem samodzielnego prowadzenia prac badawczo-rozwojowych. Ponadto do wykorzystywania transferu technologii istotnie pobudza łatwy w mniemaniu respondentów - dostęp do nowej technologii oraz bezpośrednio powiązany z tą łatwością dynamiczny rozwój technologii informatycznych i telekomunikacyjnych.

$\mathrm{W}$ najmniejszym stopniu oddziałuje $\mathrm{w}$ analizowanym zakresie groźba kryzysów finansowych, ale jednak pobudzająco. Ostatnie doświadczenia sektora przekonują, że wystąpienie kryzysu finansowego jest realnym zagrożeniem i jak się okazuje, wyposażenie się w nowo- 
czesne technologie jest postrzegane jako jedna z form przeciwdziałania ich negatywnym skutkom.

Tabela 3. Zewnętrzne stymulatory wykorzystywania transferu technologii

\begin{tabular}{|l|c|c|c|c|c|c|}
\hline \multirow{2}{*}{$\begin{array}{c}\text { Zewnętrzne stymulatory transferu } \\
\text { technologii }\end{array}$} & \multicolumn{5}{|c|}{ Średnia ocen wpływu } \\
\cline { 2 - 7 } & CP & ZUM & ZUnŻ & Banki & TFI & PTE \\
\hline $\begin{array}{l}\text { Możliwość zweryfikowania skutecz- } \\
\text { ności nowych technologii }\end{array}$ & 4,2 & 5,0 & 4,5 & 3,8 & 3,9 & 4,1 \\
\hline $\begin{array}{l}\text { Wysoka opłacalność wdrażania no- } \\
\text { wych technologii przez transfer tech- } \\
\text { nologii }\end{array}$ & 4,2 & 5,0 & 4,5 & 4,0 & 3,9 & 3,8 \\
\hline Łatwy dostęp do nowej technologii & 4,1 & 5,0 & 4,5 & 3,4 & 3,9 & 4,0 \\
\hline $\begin{array}{l}\text { Dynamiczny rozwój technologii in- } \\
\text { formatycznych i telekomunikacyjnych }\end{array}$ & 4,1 & 5,0 & 4,3 & 3,8 & 3,7 & 3,9 \\
\hline $\begin{array}{l}\text { Wielość źródeł informacji o nowych } \\
\text { technologiach }\end{array}$ & 4,0 & 5,0 & 4,6 & 3,1 & 3,6 & 3,9 \\
\hline Presja rosnącej konkurencji & 4,0 & 4,7 & 4,2 & 3,6 & 3,6 & 4,0 \\
\hline Zasoby Internetu & 4,0 & 4,8 & 4,4 & 3,4 & 3,6 & 3,7 \\
\hline $\begin{array}{l}\text { Aktywność przedsiębiorstw i instytucji } \\
\text { oferujących transfer technologii }\end{array}$ & 3,9 & 5,0 & 4,2 & 3,0 & 3,7 & 3,9 \\
\hline Proces globalizacji gospodarek & 3,9 & 5,0 & 4,3 & 3,2 & 3,4 & 3,8 \\
\hline $\begin{array}{l}\text { Dostęp do zewnętrznych źródeł finan- } \\
\text { sowania }\end{array}$ & 3,9 & 5,0 & 4,5 & 3,0 & 3,5 & 3,4 \\
\hline $\begin{array}{l}\text { Pomoc instytucji wspomagających } \\
\text { transfer technologii }\end{array}$ & 3,9 & 5,0 & 4,3 & 2,7 & 3,8 & 3,6 \\
\hline Groźba kryzysów finansowych & 3,8 & 3,7 & 4,3 & 3,3 & 4,0 & 3,8 \\
\hline
\end{tabular}

$\mathrm{CP}$ - cała próba badanych przedsiębiorstw $(\mathrm{N}=90)$

ZUM - zakłady ubezpieczeń majątkowych $(\mathrm{N}=20)$

ZUnŻ - zakłady ubezpieczeń na życie $(\mathrm{N}=20)$

$\mathrm{B}$ - banki $(\mathrm{N}=20)$

TFI - towarzystwa funduszy inwestycyjnych $(\mathrm{N}=20)$

$\mathrm{PTE}$ - powszechne towarzystwa emerytalne $(\mathrm{N}=10)$

Źródło: opracowanie własne na podstawie wyników badań ankietowych. 
Analizując wyniki warto jeszcze zwrócić uwagę na różnice występujące $w$ ewaluowanych branżach. Ocena siły oddziaływania zewnętrznych stymulatorów w poszczególnych branżach wskazuje, że najsilniej wpływają one na decyzje o wykorzystaniu transferu technologii podejmowane przez zakłady ubezpieczeń, przede wszystkim majątkowych, a najsłabiej - na decyzje banków. W konsekwencji w zasadzie tylko banki mają wątpliwości, czy niektóre czynniki, a zwłaszcza aktywność instytucji oferujących i wspomagających transfer technologii oraz dostęp do zewnętrznych źródeł finansowania miały istotne znaczenie $\mathrm{w}$ procesie decyzyjnym rozstrzygającym o wykorzystaniu w swej prorozwojowej działalności transferu technologii. Wskazując na różnice warto dodać, że czynniki mające najmniejszy wpływ na banki, zostały ocenione przez zakłady ubezpieczeń majątkowych jako wyraźnie stymulujące.

$\mathrm{W}$ ramach podsumowania na rysunku 2 zostały przedstawione w układzie graficznym najsilniej oddziałujące na przedsiębiorstwa finansowe stymulatory wykorzystywania transferu technologii.

\section{Rysunek 2. Główne zewnętrzne stymulatory wykorzystywania transfe- ru technologii}

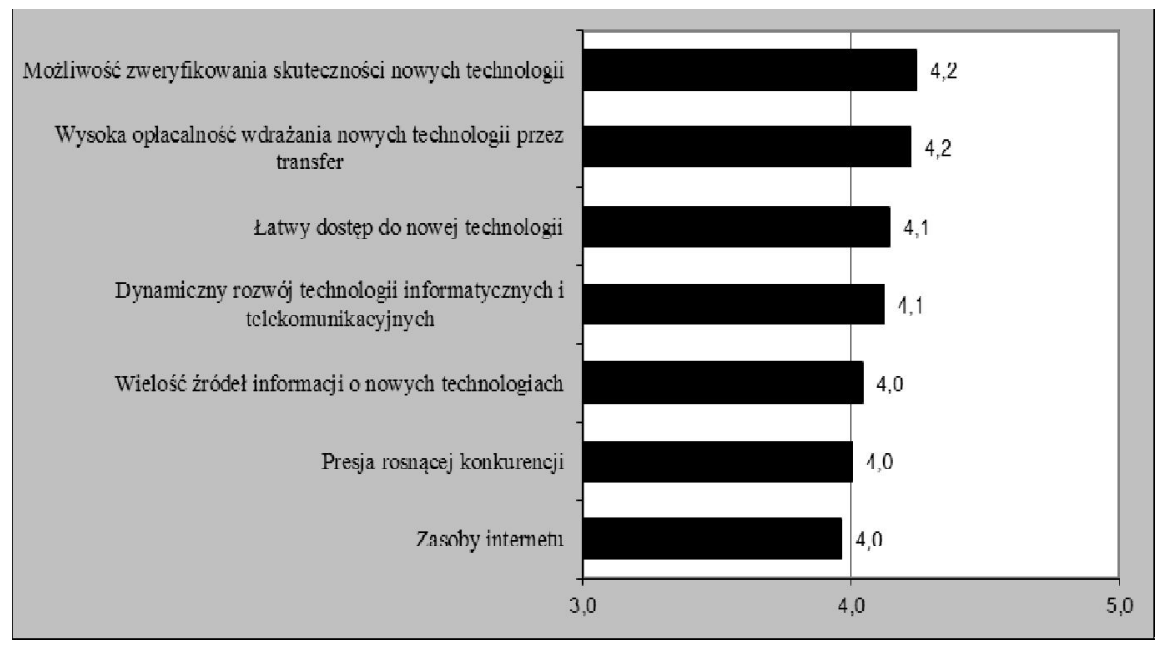

Źródło: opracowanie własne na podstawie wyników badań ankietowych. 
Jak wynika z zaprezentowanego obrazu, działające w Polsce przedsiębiorstwa finansowe dostrzegają wiele wyraźnych bodźców stymulujących do sięgania po formę transferu w ramach procesu pozyskiwania nowych technologii. Innymi słowy dostrzegają one sprzyjające warunki do podejmowania działań na rzecz rozwoju swojego potencjału za sprawą transferu technologii i jak się okazuje, wykorzystują je.

W kolejnym kroku analiz podjęto próbę odpowiedzi na pytanie: jakie elementy otoczenia ograniczają przedsiębiorstwa usług finansowych w zakresie absorbowania z zewnątrz nowych technologii? W odniesieniu do czynników destymulujących została zastosowana ta sama procedura i skala oceniania, co w przypadku stymulant. $\mathrm{W}$ konsekwencji w tabeli 4 autor prezentuje zidentyfikowaną siłę hamującego oddziaływania zewnętrznych barier wykorzystywania transferu technologii, obrazując tym samym zakres postrzegania zagrożeń płynących z otoczenia organizacji.

Przedstawione wyniki badań sugerują, że menedżerowie przedsiębiorstw finansowych nie napotykają w swym otoczeniu zagrożeń istotnie ograniczających wdrażanie nowych technologii drogą transferu. Z drugiej jednak strony nie bagatelizują hamującego wpływu żadnego $\mathrm{z}$ analizowanych czynników. W zasadzie w odniesieniu do wszystkich z nich - średnio rzecz ujmując - trudno im jednoznacznie opowiedzieć się, czy są one znaczące czy nie. Tym samym nie odczuwają wyraźnego zagrożenia ze strony potencjalnych barier, ale też nie lekceważą ich znaczenia, co świadczy o ich strategicznej wrażliwości oraz o poczuciu odpowiedzialności za technologiczny rozwój zarządzanych przez siebie przedsiębiorstw.

Pośród tych porównywalnie ocenionych czynników najwyższą uśrednioną ocenę uzyskał wysoki poziom kosztów działań związanych $\mathrm{z}$ transferem technologii oraz obowiązujące przepisy prawa i procedury administracyjne, a także bardzo dynamicznie zachodzące w otoczeniu zmiany, w tym dotyczące potrzeb klientów. Zatem przede 
wszystkim to te aspekty mogą stanowić rzeczywiste bariery dla podejmowania aktywności przedsiębiorstw finansowych na rzecz transferu technologii.

\section{Tabela 4. Zewnętrzne bariery wykorzystywania transferu technologii}

\begin{tabular}{|l|c|c|c|c|c|c|}
\hline \multicolumn{1}{|c|}{$\begin{array}{c}\text { Zewnętrzne bariery transferu } \\
\text { technologii }\end{array}$} & \multicolumn{5}{|c|}{ Średnia ocen wpływu } \\
\cline { 2 - 7 } & CP & ZUM & ZUnŻ & Banki & TFI & PTE \\
\hline $\begin{array}{l}\text { Wysokie koszty działań związanych z } \\
\text { transferem technologii }\end{array}$ & 3,5 & 4,7 & 2,5 & 3,3 & 3,7 & 3,6 \\
\hline $\begin{array}{l}\text { Przepisy prawa i procedury admini- } \\
\text { stracyjne }\end{array}$ & 3,5 & 4,9 & 2,1 & 3,6 & 3,5 & 3,5 \\
\hline $\begin{array}{l}\text { Bardzo dynamiczne zmiany otoczenia, } \\
\text { w tym zmiany potrzeb klientów }\end{array}$ & 3,4 & 4,4 & 2,3 & 3,7 & 3,4 & 3,4 \\
\hline $\begin{array}{l}\text { Niska opłacalność wdrażania nowych } \\
\text { technologii przez transfer technologii }\end{array}$ & 3,3 & 4,6 & 2,0 & 3,0 & 4,1 & 3,2 \\
\hline Wysokie koszty zakupu technologii & 3,3 & 4,8 & 2,4 & 3,0 & 3,4 & 3,2 \\
\hline $\begin{array}{l}\text { Brak lub trudny dostęp do instytucji } \\
\text { wspierających transfer technologii }\end{array}$ & 3,3 & 4,6 & 2,0 & 2,7 & 4,1 & 3,2 \\
\hline $\begin{array}{l}\text { Zbyt niski popyt na usługi świadczone } \\
\text { w oparciu o wysoką technologię }\end{array}$ & 3,3 & 4,9 & 2,3 & 3,0 & 3,2 & 3,2 \\
\hline $\begin{array}{l}\text { Niski poziom rynkowych wymagań } \\
\text { klientów }\end{array}$ & 3,2 & 4,8 & 2,1 & 3,1 & 3,0 & 3,5 \\
\hline $\begin{array}{l}\text { Pasywna postawa potencjalnych part- } \\
\text { nerów w transferze technologii }\end{array}$ & 3,2 & 4,4 & 2,1 & 2,9 & 3,5 & 3,3 \\
\hline $\begin{array}{l}\text { Zbyt duże koszty zewnętrznych źródeł } \\
\text { finansowania }\end{array}$ & 3,1 & 4,7 & 1,9 & 3,1 & 3,0 & 2,9 \\
\hline $\begin{array}{l}\text { Ograniczony dostęp do specjalistycz- } \\
\text { nej kadry na rynku pracy }\end{array}$ & 3,0 & 4,3 & 1,6 & 2,9 & 3,3 & 3,1 \\
\hline
\end{tabular}

$\mathrm{CP}$ - cała próba badanych przedsiębiorstw $(\mathrm{N}=90)$

ZUM - zakłady ubezpieczeń majątkowych $(\mathrm{N}=20)$

ZUnŻ - zakłady ubezpieczeń na życie $(\mathrm{N}=20)$

$\mathrm{B}-$ banki $(\mathrm{N}=20)$

TFI - towarzystwa funduszy inwestycyjnych $(\mathrm{N}=20)$

PTE - powszechne towarzystwa emerytalne $(\mathrm{N}=10)$

Źródło: opracowanie własne na podstawie wyników badań ankietowych.

Z kolei w najmniejszym stopniu upatrywane są zagrożenia w ograniczonym dostępie do specjalistycznej kadry na rynku pracy 
i w zbyt wysokich kosztach zewnętrznych źródeł finansowania. Oznacza to, że firmy sektora finansowego nie mają większych problemów ze swoim intelektualnym, jak i finansowym kapitałem, a zatem w tym obszarze wydają się mieć raczej komfortowe warunki protechnologicznego rozwoju.

Również w przypadku barier można zaobserwować rozbieżność poglądów wśród przedstawicieli badanych branż w odniesieniu do siły ich oddziaływania. Okazuje się, że są one najsilniej odczuwane ponownie przez zakłady ubezpieczeń majątkowych, ale najsłabiej już nie przez banki, a przez zakłady ubezpieczeń na życie, co wydaje się dość zaskakujące $\mathrm{z}$ uwagi na podobieństwo potencjałów zakładów ubezpieczeń majątkowych i na życie należących niejednokrotnie do tych samych grup kapitałowych. Analizując zidentyfikowane bariery w poszczególnych branżach dostrzega się takie, które są postrzegane jako silnie oddziałujące, jak i nieistotne z punktu widzenia ich hamującego wpływu. Ponadto są takie, które przez jedne branże są traktowane jako silnie destymulujące, a przez inne - słabo. A zatem różnice w ich postrzeganiu wydają się być znaczące.

Stanowiący podsumowanie graficzny obraz najsilniej odczuwanych przez badane przedsiębiorstwa barier wykorzystywania transferu technologii został przedstawiony na rysunku 3.

Wysoka aktywność przedsiębiorstw finansowych w zakresie pozyskiwania z otoczenia nowych technologii świadczy o tym, iż skutecznie radzą sobie one $\mathrm{z}$ występującymi $\mathrm{w}$ tym zakresie przeciwnościami, albowiem dowiedziono, że takowe faktycznie miały miejsce. Analizując poglądy respondentów dotyczące istotności zidentyfikowanych barier stosowania transferu technologii, należy uznać, że ich siła hamującego oddziaływania jest istotnie mniejsza niż sprzyjający wpływ dostrzeganych i odczuwanych stymulatorów. Uzasadnia to fakt, iż działające w Polsce przedsiębiorstwa finansowe tak licznie 
i aktywnie wykorzystują formę transferu w procesie budowania własnego potencjału technologicznego ${ }^{12}$.

\section{Rysunek 3. Główne zewnętrzne bariery wykorzystywania transferu technologii}

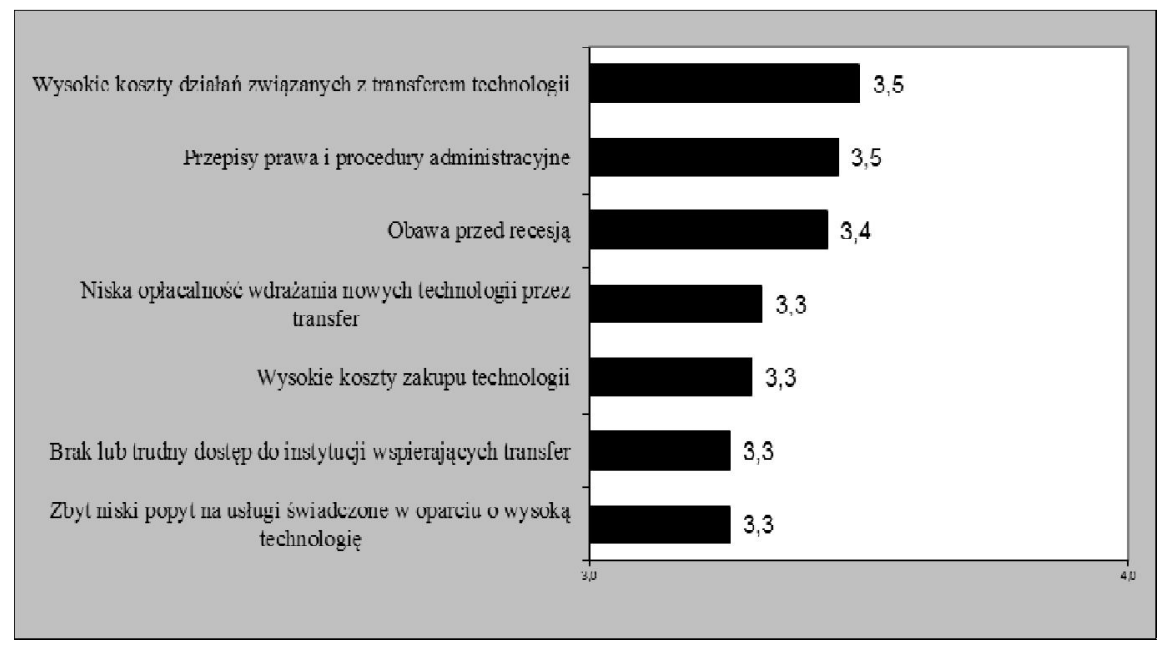

Źródło: opracowanie własne na podstawie wyników badań ankietowych.

Konstatując powyższe spostrzeżenia można stwierdzić, że menedżerowie przedsiębiorstw finansowych co prawda dostrzegają realne zagrożenia występujące $w$ ich otoczeniu i odczuwa względem nich respekt, jednak nie poddaje się ich negatywnemu oddziaływaniu i nie ogranicza z ich powodów swej aktywności w zakresie transferu technologii.

Choć należą do zdecydowanej mniejszości, to są jednak też takie przedsiębiorstwa $\mathrm{w}$ badanym sektorze finansowym, które nie inwestowały w ostatnich 3 latach w nowe technologie, a tym samym nie podejmowały się ich transferu i bynajmniej nie dlatego, że nie czuły

\footnotetext{
12 Szerzej na temat uwarunkowań wykorzystywania transferu technologii przez przedsiębiorstwa polskiego sektora finansowego zob. W. Glabiszewski, Conditions for Using Technology Transfer as a Form of Developing Competitive Potential in Companies of the Polish Financial Sector, [w:] E. Lechman (ed.), Enterprise in Modern Economy. Innovations, vol. 1, Publishing House of Gdańsk University of Technology, Gdańsk 2010, s. 112-118.
} 
takiej potrzeby. Po prostu napotkały na trudności, z którymi nie były w stanie sobie poradzić. Wśród najczęściej podawanych przyczyn takiego stanu rzeczy wg kolejności częstotliwości ich wskazywania znalazły się:

1. brak prowadzonej działalności badawczo-rozwojowej,

2. brak środków finansowych,

3. brak dostępu do nowych technologii,

4. brak inwestora strategicznego,

5. brak doradztwa w zakresie nowych technologii,

6. niska opłacalność inwestycji w nowe technologie,

7. brak wiedzy o nowych technologiach.

Z powyższego wynika, że wśród najczęściej deklarowanych przez badane firmy przyczyn niepodejmowania w ostatnich 3 latach inwestycji w nowe technologie znajdują się te wewnątrzorganizacyjne, stanowiąc o ich konkretnych słabościach. Dopiero w dalszej kolejności są wymieniane czynniki zewnętrzne, takie jak brak doradztwa w zakresie nowych technologii i niska opłacalność inwestycji w nowe technologie.

\section{Podsumowanie}

Przeprowadzona w ramach niniejszego opracowania analiza wyników badań ankietowych pozwala stwierdzić, iż działające w Polsce przedsiębiorstwa sektora finansowego, mimo że reprezentują sferę usług, są świadome potrzeby rozwoju swojego potencjału technologicznego i wykazują się dużą aktywnością w zakresie wdrażania nowych technologii, pozyskując je bardzo często drogą transferu.

Sama świadomość znaczenia technologii i jej transferu dla rozwoju potencjału przedsiębiorstwa nie wystarczy jednak, aby podejmować w tym obszarze konkretne działania. Są one bowiem uzależnione również od wewnętrznych możliwości organizacji i zewnętrznych sposobności. Okazuje się, że panujące w otoczeniu warunki po- 
dejmowania transferu technologii są oceniane przez zainteresowanych jej pozyskaniem jako sprzyjające. Dostrzegają oni wiele czynników, które wystarczająco silnie pobudzają je do angażowania się w przedsięwzięcia mające na celu pozyskanie nowych technologii, by się ich podjąć. Wśród najistotniejszych stymulatorów należy wymienić możliwość wcześniejszego weryfikowania skuteczności nowych technologii, wysoką opłacalność ich wdrażania drogą transferu, a także bardzo dynamiczne zmiany w otoczeniu, w tym odnoszące się do potrzeb klientów. Ponadto pojawiające się na tej płaszczyźnie bariery, które są rzeczywiście dostrzegane i poważnie traktowane przez badane przedsiębiorstwa, nie mają tak dużej siły sprawczej, aby mogły powstrzymać je przed realizacją działań zmierzających do przetransferowania nowych technologii do wewnętrznych zastosowań. Do najpoważniejszych, aczkolwiek nie aż tak bardzo destymulujących czynników należy zaliczyć poziom kosztów działań związanych $\mathrm{z}$ transferem technologii oraz przepisy prawa i procedury administracyjne, a także obawy przed recesją.

Ostatecznie warunki panujące $w$ otoczeniu przedsiębiorstw finansowych w Polsce należy uznać za sprzyjające, gdyż dostarczają im wystarczająco dużo przesłanek skłaniających do wykorzystywania formy transferu w celu zapewnienia rozwoju swojego potencjału technologicznego.

Warto jeszcze dodać, iż poszczególne branże polskiego sektora finansowego często w wyraźnie odmienny sposób postrzegają uwarunkowania decyzji o wykorzystaniu w ramach swej innowacyjnej działalności transferu technologii, niemniej jednak okazuje się, że te decyzje podejmują.

\section{Bibliografia:}

Agmon T., von Glinow M.A., Technology transfer in international business, Oxford University Press, New York 1991. 
Gierszewska G., Romanowska M., Analiza strategiczna przedsiębiorstwa, PWE, Warszawa 2003.

Glabiszewski W., Conditions for Using Technology Transfer as a Form of Developing Competitive Potential in Companies of the Polish Financial Sector, [w:] Enterprise in Modern Economy. Innovations, vol. 1, E. Lechman (ed.), Publishing House of Gdańsk University of Technology, Gdańsk 2010.

Glabiszewski W., Transfer technologii $w$ działalności innowacyjnej przedsiębiorstw usług finansowych, „Zeszyty Naukowe Ekonomia i Zarządzanie" 2013, t. VI.

Narayanan V.K., Managing technology and innovation for competitive advantage, Prentice Hall, New Jersey 2001.

Miles J.A., Management and Organization Theory, Jossey-Bass Reader, San Francisco 2012.

Porter M.E., Competitive Strategy. Techniques for Analyzing Industries and Competitors, The Free Press, New York 1998.

Robbins S.P., Management. Concepts and applications, Printice-Hall International, New Jersey 1988.

Stawasz E., Innowacje a mała firma, Wydawnictwo Uniwersytetu Łódzkiego, Łódź 1999.

Stoner J.A.F., Freeman R.E., Gilbert D.R., Jr., Kierowanie, PWE, Warszawa 2001.

Sudoł S., Przedsiębiorstwo. Podstawy nauki o przedsiębiorstwie. Zarzqdzanie przedsiębiorstwem, PWE, Warszawa 2006. 
Trott P., Innovation Management and New Product Development, Prentice Hall, Harlow 2008. 